\title{
9 \\ Employment growth, labour scarcity and the nature of China's trade expansion
}

\section{Cai Fang and Dewen Wang}

Since the mid 1990s, China has deepened its reforms of state-owned enterprises, urban employment and social welfare systems in order to improve the efficiency of state-owned enterprises and enhance their survival capabilities in the face of fierce international competition. The reforms have released millions of rendundant urban workers and the issue of unemployment has become a top priority in Chinese social and economic policies.

China finally joined the World Trade Organization (WTO) late in 2001. Some commentators predicted that accession to the WTO might worsen urban unemployment. Rapid trade expansion has, however, not only fuelled Chinese economic growth, it has created more job opportunities by expanding nonagricultural sectors, mitigating the severe pressure of urban unemployment.

The emergence of a shortage of rural migrant workers signals, to a certain extent, the transition in the rural labour force supply from an unlimited to a limited surplus (Cai and Wang 2005, Wang et al. 2006). The wages of rural migrant workers have grown at an average annual rate of more than 10 per cent in recent years. If this trend continues, and unless labour productivity grows rapidly, increases in labour costs will be unavoidable, threatening the competitiveness of Chinese manufacturing industry.

This chapter has four parts. Part one examines employment growth and changing situations of urban employment. Part two describes the trade expansion and its impact on employment growth. Part three discusses labour scarcities and their impact on the international competitiveness of Chinese manufacturing. The chapter concludes with a discussion of some policy implications. 
The Turning Point in China's Economic Development

\section{Employment growth and changing situations of urban employment}

\section{Economic and employment growth}

Economic growth is a precondition for employment growth. Okun's Law states that there is a negative relationship between economic growth and unemployment. Empirical experiences from the United States indicate that a 1 per cent addition to GDP growth will lower the unemployment rate by 2 per cent (Mankiw 2003). Economic booming (or recession) often causes the acceleration (or slowdown) of employment growth. The Chinese economy experienced a boom in the first half of the 1990s, with an average 12 per cent annual growth rate, and a slowdown in the second half of the 1990s, with an average 8.3 per cent annual growth rate. Since 2001, Chinese growth has accelerated, with an average annual growth rate of 8.9 per cent (Table 9.1).

According to Okun's Law, employment growth should have been faster in the period between 1991 and 1995 than in the other two five-year periods. But the growth of total employment seems to contradict Okun's Law; it grew faster between 1996 and 2000 than in the other two five-year periods.

The growth of total employment was 1 per cent in the first half of the 1990s, 1.2 per cent in the second half of the 1990s and 1 per cent per annum in the first five years of the new century (Table 9.1). The inclusion of agricultural employment is the main reason for this paradox. In a traditional dual economy, the agricultural sector plays a role as a supplier of surplus labour to the modern economy in the process of economic expansion (or contraction). If we exclude agricultural employment, the growth of non-agricultural employment in the industrial and service sectors is consistent with the predicted direction in terms of Okun's Law.

GDP growth in the first half of the 1990s was 3-4 percentage points higher than in the second half of the 1990s and in the first five years of this century, so the growth of non-agricultural employment in the first half of the 1990s was also higher. From 1991 to 2005, employment growth had cyclical characteristics. Employment growth in secondary and tertiary industries in the first half of the 1990s was fastest, with average annual rates of 2.5 per cent and 7.1 per cent, respectively, while they dropped to 0.7 per cent and 3.3 per cent in the second half of the 1990s, and rose to 2.3 per cent and 3.7 per cent in the first five years of this century.

Economic growth is not a sufficient condition for fast employment growth because it can be driven by huge investment or the expansion of capital-intensive sectors. In an economy with abundant labour resources, cheap labour is the source of its 


\section{Table 9.1 GDP and employment growth in China, 1991-2005}

\begin{tabular}{lccc}
\hline & $1991-95$ & $1996-2000$ & $2001-05$ \\
GDP growth (per cent) & & & \\
Total & 12.0 & 8.3 & 8.9 \\
Agriculture & 4.2 & 3.5 & 3.9 \\
Secondary industries & 17.5 & 9.8 & 10.7 \\
Tertiary industries & 10.0 & 8.2 & 8.6 \\
Employment growth (per cent) & 1.0 & & \\
Total & -1.8 & 1.2 & 1.0 \\
Agriculture & 2.5 & 0.3 & -1.2 \\
Secondary industries & 7.1 & 0.7 & 2.3 \\
Tertiary industries & & 3.3 & 3.7 \\
Employment elasticity & 0.08 & 0.14 & 0.11 \\
Total & -0.43 & 0.09 & -0.29 \\
Agriculture & 0.14 & 0.07 & 0.21 \\
Secondary industries & 0.71 & 0.40 & 0.43 \\
Tertiary industries & & & \\
\hline
\end{tabular}

Sources: National Bureau of Statistics of China, 2005a. China Statistical Yearbook 2005, China Statistics Press, Beijing. National Bureau of Statistics of China, 2006d. The Statistical Communiqué on the 2005 National Economic and Social Development, 28 February.

comparative advantage. If the development strategy follows the principle of comparative advantage to maximise the utilisation of its abundant labour resources, rapid economic growth can involve fast employment growth.

Employment elasticity measures the ratio of employment growth to output growth. If rapid economic growth leads to fast employment growth, its employment elasticity is high; otherwise, its employment elasticity is low. In Table 9.1, total employment elasticities do not change much over time due to the buffering effect of agricultural employment; that is, agricultural employment declines when an economic boom drives the expansion of non-agricultural sectors to absorb the transfer of the rural labour force, but it increases when economic recession releases labourers from non-agricultural sectors.

The employment elasticities in the secondary and tertiary sectors were higher in the first half of the 1990s, when Deng Xiaoping ushered in an economic boom, but they declined in the second half of the 1990s, when the central government started to deepen reforms of state-owned enterprises and urban social security systems.

Since 2001, accession to the WTO has supported the acceleration of economic growth and employment through unprecedented trade expansion. The employment elasticities in secondary and tertiary sectors rose above the levels of the late 
1990s. The big jump in employment elasticity in the secondary sector was due mainly to the acceleration of export growth, which stimulated the expansion of the manufacturing sectors.

Employment growth differs between urban and rural areas and across different types of enterprises (Table 9.2). Urban employment has maintained fast growth since 1990 and reached 264.8 million in 2004. Between 1991 and 2004, average urban employment growth was 3.2 per cent annually. In contrast, average rural employment growth was 0.1 per cent in the same period. The decomposition of employment by types of enterprise ownership reveals the dramatic adjustment of employment structure.

In urban areas, the downsizing of state-owned and collective enterprises released millions of redundant workers. Employment growth in state-owned and collective units was at the average rate of -3 per cent and -9.2 per cent annually between 1991 and 2004, respectively, causing the sum of their shares in total urban employment to decline from 79 per cent to 32.5 per cent in the same period. Meanwhile, employment growth in the newly emerged non state-owned enterprise units, such as limited-liability corporations, shareholding corporations, private enterprises, enterprises with funds from Hong Kong, Macao and Taiwan, foreignfunded enterprises and self-employed businesses, increased rapidly, accounting for an average of 19.8 per cent of total urban employment between 2001 and 2004.

The dramatic expansion of self-employment in the 1990 s and employment in undefined units (urban employment residuals) in the second half of the 1990s illustrates the increasing diversification and informalisation of urban employment. Statistically, the substantial increase of unit employment in such newly emerged non state-owned enterprise sectors does not sufficiently offset the decline in state and collective employment, causing a residual between classified and total employment. This residual accounted for 11.3 per cent in the first half of the 1990s, and increased to 38.4 per cent of total urban employment between 2001 and 2004.

The expansion of the missing employment not only emphasises the incapacity of the traditional labour statistics to reflect the actual labour market situation under the diversified and complicated economic structure. It also reflects increasingly severe unemployment and urban employment protection. In order to protect local employment, local governments often implement short-term policies that obstruct the expansion of the labour market, intervene in labour adjustment in enterprises and sometimes ask enterprises not to hire outside labourers (Cai et al. 2001). Entry barriers to formal sectors and social exclusion have left migrants and low-skilled workers being employed mainly in informal sectors with poor working 


\begin{tabular}{|c|c|c|c|c|c|c|}
\hline \multirow[t]{3}{*}{ Table 9.2} & oyment & growth in & urban a & ral areas & s, 1991-20 & \\
\hline & \multicolumn{3}{|c|}{ Growth (per cent) } & \multicolumn{3}{|c|}{ Composition (per cent) } \\
\hline & 1991-95 & $1996-2000$ & 2001-04 & 1991-95 & 1996-2000 & $2001-04$ \\
\hline \multicolumn{7}{|l|}{ Urban employment } \\
\hline Total & 2.2 & 4.0 & 3.4 & 100.0 & 100.0 & 100.0 \\
\hline $\begin{array}{l}\text { State-owned units } \\
\text { Collectively }\end{array}$ & 1.7 & -6.2 & -4.6 & 60.2 & 44.9 & 28.2 \\
\hline $\begin{array}{l}\text { owned units } \\
\text { Non-state-owned }\end{array}$ & -2.3 & -13.1 & -12.0 & 18.8 & 10.4 & 4.3 \\
\hline $\begin{array}{l}\text { enterprise units } \\
\text { Self-employed }\end{array}$ & 45.9 & 19.5 & 18.1 & 4.1 & 11.2 & 19.8 \\
\hline individuals & 20.9 & 7.0 & 4.3 & 5.6 & 9.7 & 9.2 \\
\hline Residuals & -5.5 & 38.6 & 5.4 & 11.3 & 23.8 & 38.4 \\
\hline Rural employment & & & & & & \\
\hline $\begin{array}{l}\text { Total } \\
\text { Township and }\end{array}$ & 0.5 & 0.0 & -0.1 & 100.0 & 100.0 & 100.0 \\
\hline $\begin{array}{l}\text { village enterprises } \\
\text { Private }\end{array}$ & 7.0 & 0.0 & 2.0 & 23.7 & 26.4 & 27.5 \\
\hline $\begin{array}{l}\text { enterprises } \\
\text { Self-employed }\end{array}$ & 35.2 & 19.5 & 15.7 & 0.5 & 1.6 & 3.3 \\
\hline individuals & 15.7 & 0.0 & -8.4 & 4.5 & 7.1 & 4.8 \\
\hline Agriculture & -2.4 & -0.4 & -1.0 & 71.3 & 64.9 & 64.4 \\
\hline
\end{tabular}

Note: Non-state-owned enterprise units include shareholding cooperative units, joint-ownership units, limited-liability corporations, shareholding corporations, private enterprises, units with funds from Hong Kong, Macao and Taiwan, and foreign-funded units. Urban residuals equal urban total employment minus state-owned units, collectively owned units, non-state-owned enterprise units and self-employed individuals.

Source: National Bureau of Statistics of China, 2005a. China Statistical Yearbook 2005, China Statistics Press, Beijing.

conditions, low pay and a lack of social protection. This causes a reduction in security and safety in the labour market (Solinger 2001).

In rural areas, non-agricultural employment comes from township and village enterprises (TVEs), private enterprises and self-employment. The rapid output growth of TVEs in the first half of the 1990s drove their employment growth at an average annual rate of 7 per cent, but their employment growth dropped to zero in the second half of the 1990s because the East Asian financial crisis dramatically lowered the export demands of TVEs. In order to compete with other enterprises, the development of TVEs has been capital-intensive to improve labour productivity, which further constrained the employment expansion.

Since 2001, employment growth in TVEs has kept an average annual rate of 2 per cent, which is lower than the growth of total urban employment. In 2004, there 
were 138.7 million rural workers employed in TVEs, accounting for 27.5 per cent of total rural employment. Employment in rural private enterprises grew faster, but its contribution to rural non-agricultural employment was still small because it accounted for only 3.3 per cent of total rural employment in 2004.

A new round of economic growth since 2001, driven by investment and exports, has created vast non-agricultural employment opportunities that accelerate the transfer of the rural labour force into non-agricultural sectors against the background of increasing rural-urban income disparity. This has generated a declining trend in self-employment and agricultural employment.

The changing situation of urban employment

The economic transition was carried out in an incremental way until the mid 1990s. Under the pressure of the WTO accession, the massive restructuring of stateowned enterprises, intended to touch on the stock of state-owned enterprises, signalled a more radical reform, having caused dramatic changes in labour markets (Meng et al. 2004). Since the mid 1990s, economic reform in China has entered a stage of stock adjustment with no guarantee of benefit of compensation for everybody. There have been more and more layoffs and unemployment rates have increased.

Assuming rural unemployment is trivial, we can use the aggregate statistics to calculate the urban unemployment rate at the aggregate level. From published data on components of population, we first estimate the economically active population in urban areas by subtracting rural employment from the whole country's economically active population, then we take the difference between the economically active population and the employed population as unemployed population in urban areas. By definition, the ratio of urban unemployment to the urban economic population is the unemployment rate.

Figure 9.1 illustrates the trend in the urban unemployment rate from 1990 to 2004. The aggregate unemployment rate increased sharply in the late $1990 \mathrm{~s}$, from 4 per cent in 1995 to 7.6 per cent in 2000, but then declined and was 5.8 per cent in 2004.

In urban China, there are official statistics for registered unemployment. According to the official definition, the statistics cover only those job-losers who 1) are aged 16-50 for males and $16-45$ for females, ${ }^{1} 2$ ) are not entitled to receive xiagang benefits, and 3) are locally registered as urban hukou ('waiting for employment'). Obviously, registered unemployment is not an effective indication of the real situation because it does not count workers who are unemployed but not registered, and then understates the real unemployment situation. 
Figure 9.1 Urban unemployment rate in China, 1990-2004 (per cent)

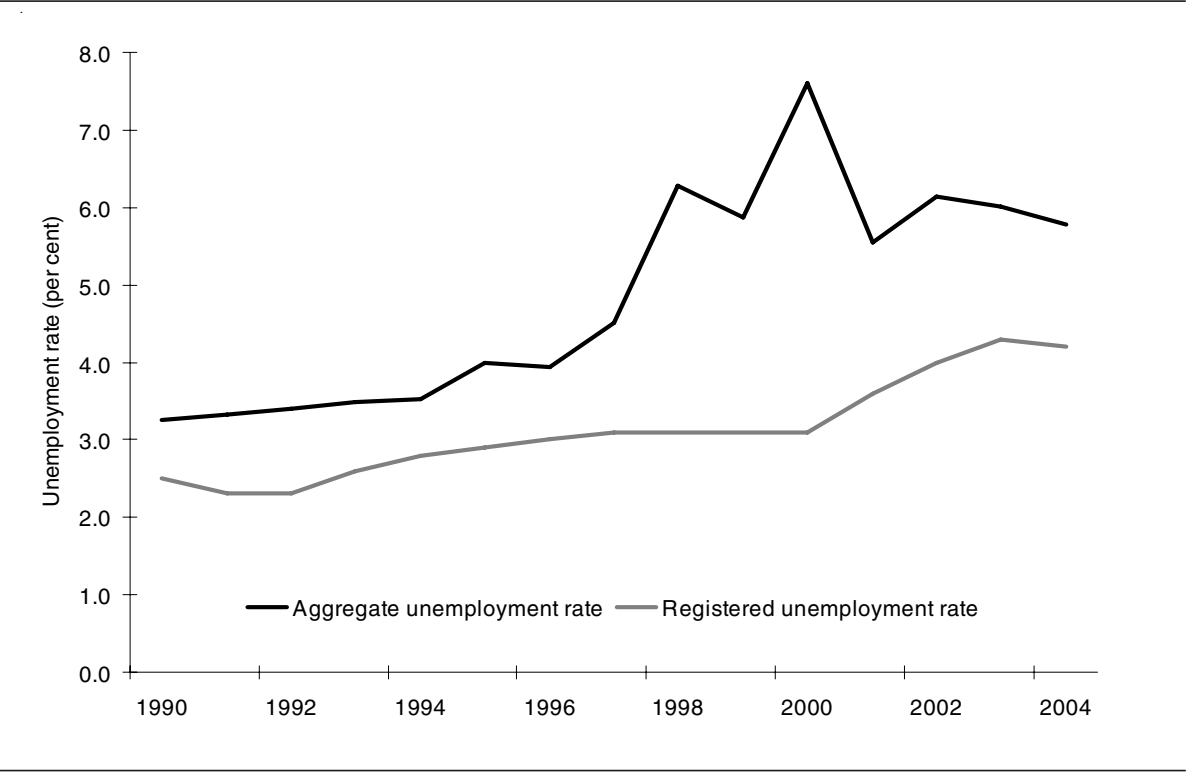

Source: National Bureau of Statistics of China, 2005a. China Statistical Yearbook 2005, China Statistics Press, Beijing.

In Figure 9.1, the registered unemployment rate is lower than the aggregate unemployment rate, and there is a large gap in the period when unemployment became more severe. Since 2000, the registered unemployment rate has kept an upward trend, which does not mean urban unemployment worsened. Rather, it represents only the provision of social protection for urban unemployed workers.

Combining the numbers of those laid off and registered unemployment also indicates a changing situation in the urban labour market from a tight to a loose status. The number of state-owned enterprise workers laid off increased from 5.9 million in 1998 to 6.6 million in 2000, but dropped afterwards (Table 9.3). In 2005, there were only 620,000 laid-off state-owned enterprise workers. The total number of laid-off workers follows a similar trend: it peaked at 9.1 million in 2000 and declined to 2.7 million in 2004. Even if we add up the total number of laid-off workers and the registered unemployed, their aggregate rose to 15.06 million in 2000 from 14.5 million, and declined to 10.9 million in 2004.

In 2000, the fifth population census asked respondents two questions about whether they were engaged in more than one hour of income-earning activities within the previous week or were looking for jobs. Based on the census data, the 


\begin{tabular}{cccc} 
Table 9.3 & $\begin{array}{l}\text { Numbers of workers laid off and registered unemployment, } \\
\text { 1998-2005 (million) }\end{array}$ & \\
\hline & $\begin{array}{c}\text { State-owned enterprise } \\
\text { workers laid off }\end{array}$ & Total laid off & $\begin{array}{r}\text { Registered } \\
\text { unemployment }\end{array}$ \\
1998 & 5.95 & 8.77 & 5.71 \\
1999 & 6.53 & 9.37 & 5.75 \\
2000 & 6.57 & 9.11 & 5.95 \\
2001 & 5.15 & 7.42 & 6.81 \\
2002 & 4.10 & 6.18 & 7.70 \\
2003 & 2.60 & 4.21 & 8.00 \\
2004 & 1.53 & 2.72 & 8.27 \\
2005 & 0.62 &.. & 8.39
\end{tabular}

Sources: National Bureau of Statistics of China, 2005a. China Statistical Yearbook 2005, China Statistics Press, Beijing. And NBS and MOLSS, Statistical Bulletin on Labour and Social Security Development, 2005.

national average urban unemployment rate was 8.3 per cent in 2000 , and the figures were larger in large cites than in small cities or towns.

The Institute of Population and Labour Economics, Chinese Academy of Social Sciences, launched a two-wave China Urban Labour Survey (CULS) in five Chinese cities (Shenyang, Wuhan, Shanghai, Fuzhou and Xian) in 2001, 2002 and 2005. Although we cannot use the average of the unemployment rates in the above five cities to infer the national average, changes in unemployment rates in those cities do help us better understand the transformation of urban employment. Unemployment rates in the five cities all went up from 1996 to 2001, but declined from 2001 to 2005, except in Xian (Table 9.4).

Changes in the ratio of job vacancies to job seekers in the urban labour market further verify that more and more job opportunities have been created since 2001. In order to monitor the situation of labour supply and demand in the urban labour market, the Ministry of Labor and Social Security established a national monitoring network in chosen cities in 2000. At the beginning of 2001, 59 cities were chosen in which to establish a centre and collect information on labour supply and demand. By the end of 2005, 116 cities had established a monitoring centre to collect data.

Using the quarterly data, we can calculate the ratio of job vacancies to job seekers to observe changes in the employment situation in the urban labour market. If the ratio is greater than one, it indicates that the urban labour market is loose, with more job vacancies; if the ratio is less than one, it indicates that the urban 


\section{Table 9.4 Urban unemployment rates in large cities, 1996-2005}

\begin{tabular}{lccccc}
\hline & January 1996 & November 2001 & August 2005 & $\begin{array}{c}\text { Changes in } \\
1996-2001\end{array}$ & $\begin{array}{c}\text { Changes in } \\
2001-05 \\
\text { Full sample }\end{array}$ \\
By city & 7.2 & 12.7 & 8.5 & 5.5 & -4.2 \\
Shanghai & 4.9 & 10.4 & 6.1 & 5.5 & -4.3 \\
Wuhan & 9.0 & 17.0 & 12.8 & 8.1 & -4.2 \\
Shenyang & 10.8 & 14.5 & 7.2 & 3.7 & -7.3 \\
Fuzhou & 5.7 & 9.8 & 5.4 & 4.1 & -4.4 \\
Xian & 7.5 & 11.2 & 11.3 & 3.6 & 0.1 \\
\hline
\end{tabular}

Sources: Institute of Population and Labour Economics, 2001, 2002 and 2005. China Urban Labour Survey, Chinese Academy of Social Sciences.

labour market is tight, with more applicants. The average ratio of job vacancies to job seekers has been increasing, from 0.65 in the first quarter of 2001 to 0.96 in the fourth quarter of 2005 , indicating that the severe pressure of urban unemployment has been largely mitigated (Figure 9.2).

It is interesting that changes in the ratios for urban workers with middle school and lower education and for those with university education are different. Since the second quarter of 2002, the ratio for urban workers with middle school and lower education was higher than the average ratio and the ratio for urban workers with a university degree, implying a rapidly increasing demand for ordinary workers. The timing coincides with the emergence of a shortage of rural workers in southern coastal regions.

\section{Trade expansion and employment growth}

Increasing openness and trade expansion

Since the reform and opening-up started in 1978, China has fundamentally transformed the basis of its development strategy from priority for heavy industry to the principle of comparative advantage. Correspondingly, the traditional regime of import substitution was gradually replaced by an export-oriented policy. In the early 1980s, China set up Special Economic Zones (SEZs) to attract and encourage foreign investment. Since the mid 1980s, China has been taking an active role in the international division of labour. China first applied for a reinstatement of its original signatory-country status in the General Agreement on Tariffs and Trade (GATT) in 1986, but its initial request was turned down. 
Figure 9.2 Ratio of job vacancies to job seekers, first quarter of 2001 to fourth quarter 2005

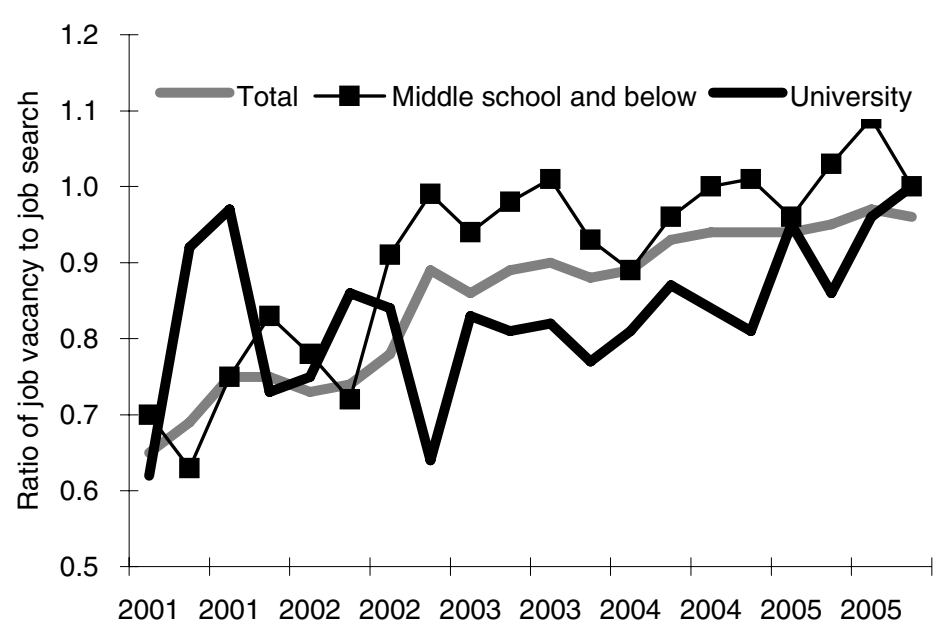

Source: Monitoring Center for China Labour Market Information, China Labour Market Network.

In order to accelerate its openness, in 1991, China decreased import tariff rates for 225 commodities and abolished import adjustment taxes. In 1992 and 1993, China continued to reduce tariff rates for 6,269 import commodities. The arithmetic average of import tariff rates in China dropped to 36.4 per cent in 1995 after five years of continuous reduction. In the meantime, China started to reform export subsidy policies and preferential credit policies for exporters, and let them take charge of their own profits and losses. In January 1994, China replaced the old fixed exchange rate regime with a single, market-based, managed floating exchange rate regime. In the same year, China started to reform the import quota system by auctioning the quota for some commodities.

In 1995, China immediately applied for membership of the WTO when it replaced GATT. In order to join the WTO, China took further measures to reduce custom tariffs and non-tariff barriers. The arithmetic average of import tariff rates was reduced to 23 per cent by the end of 1996 and further cut to 14 per cent in 2001, when China finally became a WTO member. At present, the arithmetic average of custom tariffs is 10.1 per cent for all commodities, 9.3 per cent for industrial commodities and 15.5 per cent for agricultural products. 


\section{Figure 9.3 Share of trade in GDP in China, 1978-2004 (per cent)}

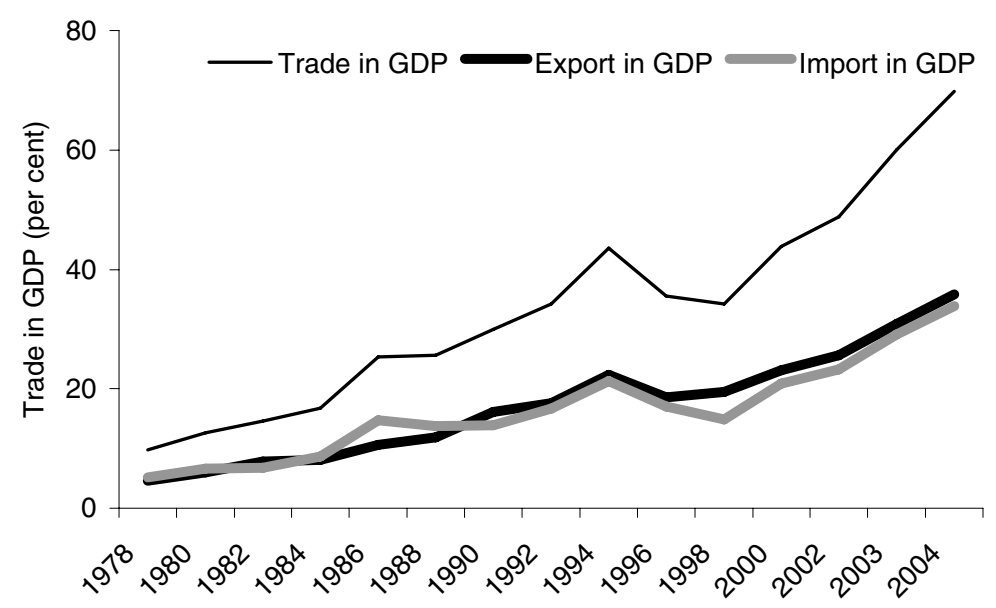

Sources: National Bureau of Statistics of China, 2003a. China Statistical Yearbook 2003, China Statistics Press, Beijing. National Bureau of Statistics of China, 2005a. China Statistical Yearbook 2005, China Statistics Press, Beijing.

As well as reducing custom tariffs, China relaxed control on import and export business rights. In 2003, the Ministry of Commerce issued a Notice on Adjusting the Standards and Approval Procedures for the Qualifications to Engage in the Import and Export Business, lowered the threshold for entrance and simplified the procedure for domestic enterprises to engage in foreign trade. In 2005, China abolished the import quota and licence system and revised the Foreign Trade Law to facilitate the expansion of foreign trade in services.

Figure 9.3 shows the increasing trend in China's trade in GDP since the reforms began. From 1978 to 1985 , the share of trade in GDP rose from 9.8 per cent to 23.1 per cent. It rose to 30 per cent from 1985 to 1990 , and continued this upward trend from 1990 to 40.2 per cent in 1995. From 1995 to 2000, it first dropped and then went up to a level a little higher than that in 1995, but close to the value in 1994.

Since 2000, Chinese foreign trade has entered an era of unprecedented rapid growth. Accession to the WTO stimulated the growth of trade and exports at an annual average rate of more than 30 per cent. The share of trade in GDP rose to 69.8 per cent in 2004, with an increase of 26.5 percentage points in two years, being the fastest increase since reforms began. 
The growth of exports and imports kept almost the same pace, but export growth was slightly faster than that of imports after the 1990s (Figure 9.3). In the 1980s, the total value of imports was greater than that of exports in most years. In the 1990 s, the total value of exports became greater than that of imports in most years. The growth of trade fluctuated over the years. In the mid 1990s, the growth of imports and exports declined sharply due to the shock of the East Asian financial crisis, but soon returned to the track of rapid growth due to the recovery of the world economy and the effect of accession to the WTO.

With rapid trade expansion, China has been quickly transformed from a major producer and consumer of agricultural and industrial products to a major player in international trade. In 1980, China accounted for only 0.9 per cent of global trade volume, ranking 26th among all countries in the world. In 2003, China's share in global trade volume rose to 5.1 per cent, ranking it fourth in the world, after the United States, Germany and Japan. Continued growth since then has lifted it into third position, behind Germany and the United States.

Trade expansion in China comes mainly from the dramatic growth in exports and imports of manufactured goods. Economic reform has gradually rectified the distortion of the traditional industrial and production structures, causing them to shift towards patterns suggested by the principle of comparative advantage.

China has comparative advantages in producing and exporting labour-intensive manufactured goods because of its cheap labour costs. It has comparative disadvantages in producing and exporting primary goods, because these are mostly natural resource-intensive (or land-intensive), and there is a shortage of natural resources (or land) per capita in China.

Changes in Chinese export structure have indeed begun to follow the principle of comparative advantage (Figure 9.4). The share of primary goods exported dropped from 50.3 per cent in 1980 to 6.8 per cent in 2004, while the share of manufactured goods exported increased to 93.2 per cent in 2004. As for the import structure, the share of primary goods imported dropped from 34.8 per cent in 1980 to 20.9 per cent in 2004 , while the share of manufactured goods imported increased to 79.1 per cent in 2004.

With China becoming more open to the outside world, changes in trade structure are an outcome of international market competition. The revealed comparative advantage index can be used to reflect the competitive position of various Chinese commodities in the international market. It equals the total export volume of a specific commodity minus its total import volume, divided by the sum of its total export and import volumes. A positive value means that the commodity has strong competitive advantages in the international market and vice versa. The 
Figure 9.4 Changing components of China's trade, 1980-2004 (per cent)

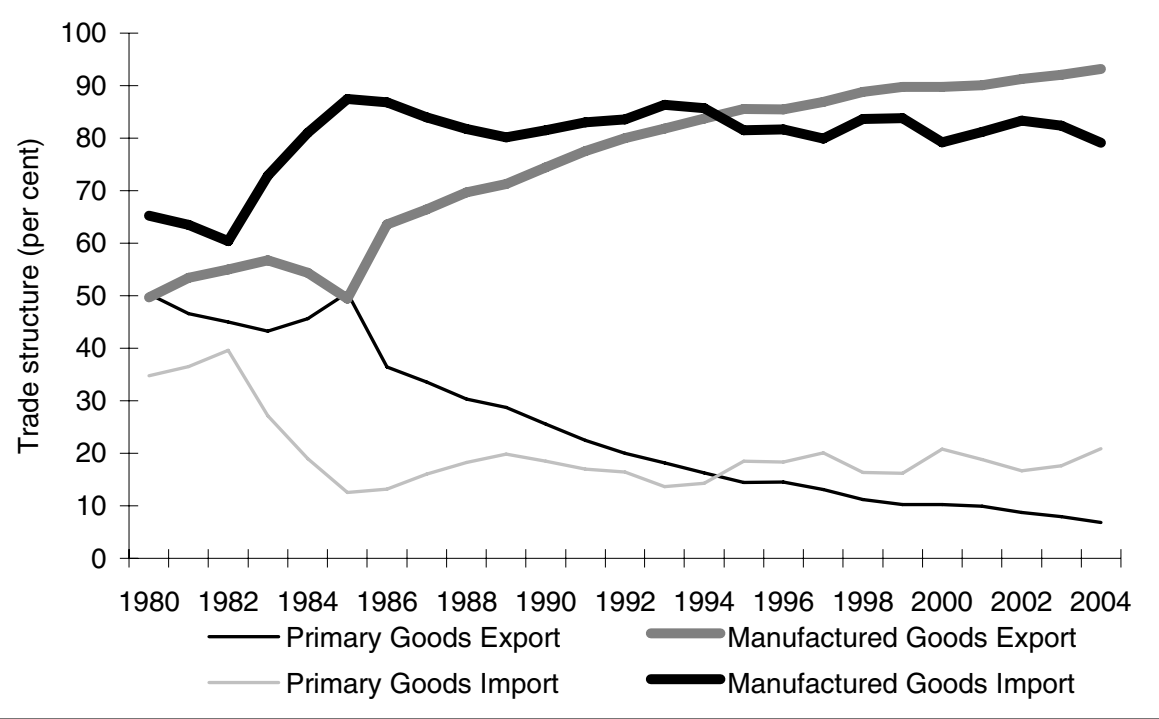

Source: National Bureau of Statistics of China, 2005a. China Statistical Yearbook 2005, China Statistics Press, Beijing.

dynamic change of the trade-competitive index indicates the intrinsic relationship between the adjustments of trade and industrial structure.

Using two-digit customs statistics, we calculated the revealed comparative indexes of 19 categories of commodities and report the results in Table 9.5. In 2004, commodities with a positive trade-competitive index included live animals and animal products; food, beverages, liquor and vinegar, tobacco and tobacco substitutes; raw hides, leather, furs and related products, saddles, travel articles, handbags and similar containers; wood and wood products, charcoal, cork and related products, straws, plaited products, baskets and wickerwork; textiles and products; footwear, headgear, umbrellas, canes, whips, processed feathers, artificial flowers, wigs; gypsum, cement, asbestos, mica, ceramic glass; natural or cultivated pearls, precious or semi-precious stones, precious metal or rolled precious metal jewellery, artificial jewellery, coins; machinery, electrical equipment and accessories, recorders, video recorders and accessories; locomotives, vehicles, aircraft, ships and related transportation equipment.

In 2004, commodities with a negative revealed comparative advantage index included vegetables, fruit and cereals; animal and vegetable oils, fats and wax, 
The Turning Point in China's Economic Development

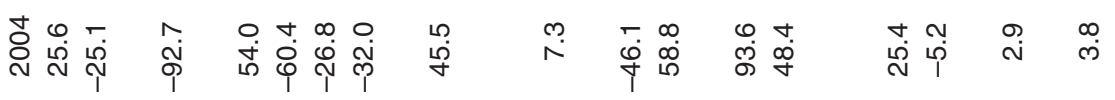

$\infty 0$

O

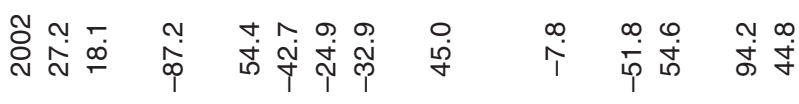

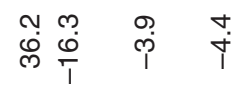

L 1

ষ্ণ

\& 8 m

๑

으

$\stackrel{0}{\hat{i}}$

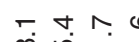

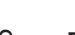

4.

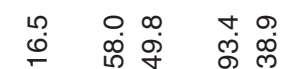

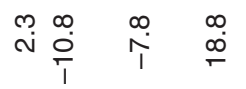

กิ

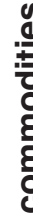

ค (2)

O

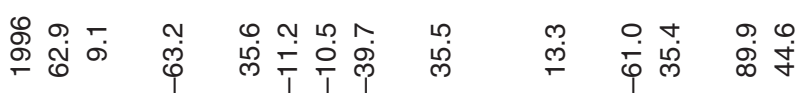

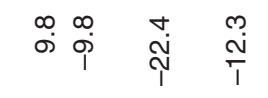

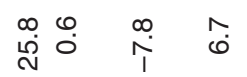

กุ 6

$+\dot{\infty}$

से กุ

$+4$

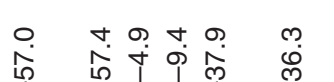

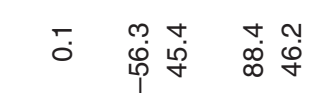

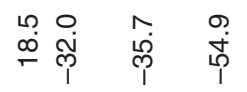

$\overline{\mathrm{N}} \underset{\infty}{\bar{\infty}}$

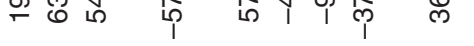

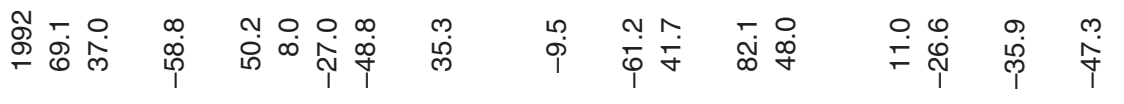

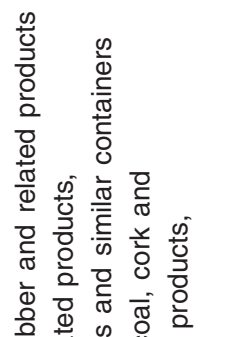

$\frac{1}{0}$
$\frac{2}{\pi}$
0
0
$\frac{1}{0}$
$\frac{\pi}{2}$
$\frac{1}{0}$
$\frac{1}{\pi}$

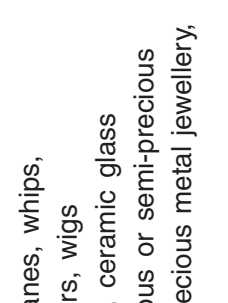

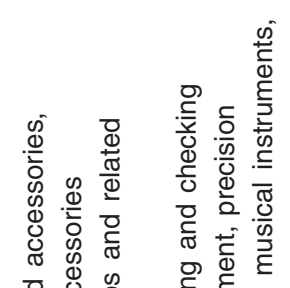

एक

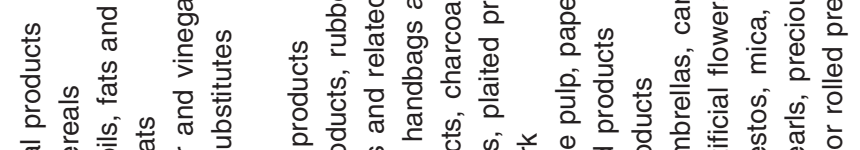

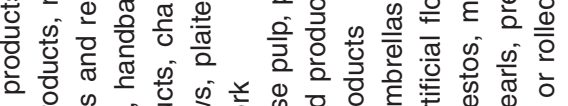

ग)

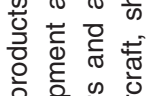

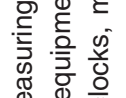

을.을 ๘

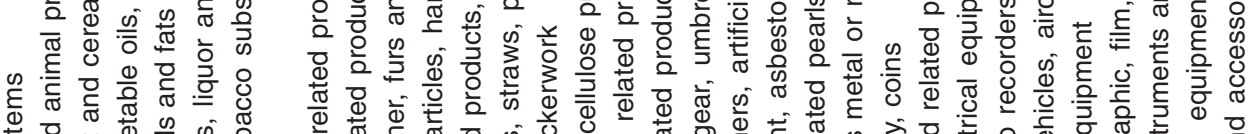

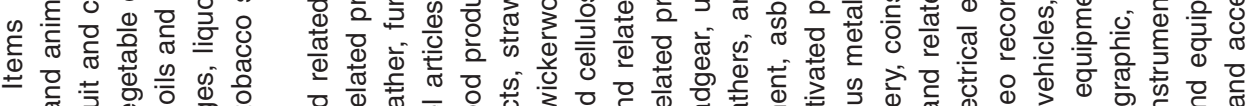

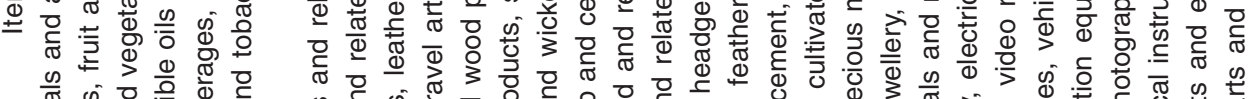

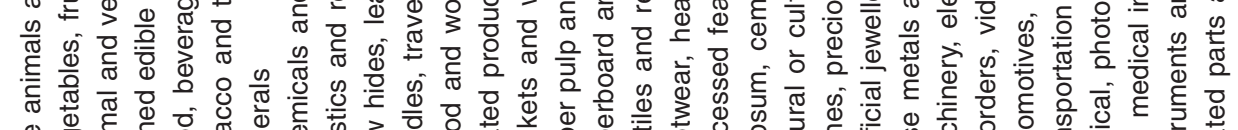

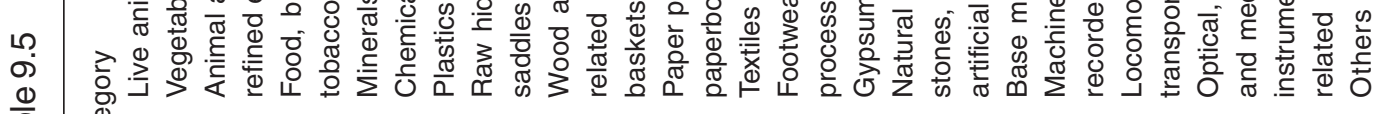
$\stackrel{0}{\stackrel{0}{*}}$ U $-N m$

으됴유

$\stackrel{10}{-} \therefore$ 
refined edible oils and fats; minerals; chemicals and related products; plastics and related products, rubber and related products; paper pulp and cellulose pulp, paper and waste paper, paperboard and related products; base metals and related products; optical, photographic, film, measuring and checking and medical instruments and equipment, precision instruments and equipment, clocks, musical instruments, related parts and accessories.

Most commodities with a positive revealed comparative advantage index were from labour-intensive industries and most commodities with a negative revealed comparative advantage index were from resource-intensive, capital-intensive or technology-intensive industries (Table 9.5).

China's exports of labour-intensive commodities have become more competitive over time. From 1992 to 2004, the revealed comparative advantage index for raw hides, leather, furs and related products rose from 35.3 per cent to 45.5 per cent. Similar increases were registered for textiles and related products, and for footwear, headgear, umbrellas, canes, whips, processed feathers, artificial flowers and wigs, with indices for the two categories soaring from 41.7 per cent to 58.8 per cent and from 82.1 per cent to 93.6 per cent, respectively.

China has, however, shown further weaknesses in exports of land-intensive and resource-intensive commodities. The revealed comparative advantage index for vegetables, fruit and cereals fell from 37.3 per cent to -25.1 per cent from 1992 to 2004. Similar declines were registered for animal and vegetable oils, fats and wax, refined edible oils and fats as well as minerals, with the indices for the two categories moving down from -58.8 per cent to -92.7 per cent and from 8 per cent to -60.4 per cent, respectively.

With the enlargement of production capacity and improvement of production structure, China's manufacturing industry has gained competitiveness in exports of machinery, vehicles and base metals. The revealed comparative advantage indices for these three categories rose from -35.9 per cent, -47.3 per cent and 26.6 per cent in 1992 to 2.9 per cent, 3.8 per cent and -5.2 per cent in 2004, respectively.

\section{Impact of trade on employment growth and structure}

According to the Heckscher Ohlin theory of comparative advantage based on factor endowments, two countries with different production-factor endowments can benefit from the production and exchange of products. The participation in international trade not only improves specialisation, it increases the number and types of consumable goods. This process allows trade to divert the accumulative pattern of physical and human capital, and reshape the steady-state condition of 
economic growth in both countries, giving rise to higher growth rates for both countries than in a closed economy. Therefore, the fundamental transformation of resource allocation from an import-substitution strategy towards an export-oriented strategy is vital for long-term economic growth (Krueger 1998). Empirical studies demonstrate that trade has significantly positive impacts on economic growth (Edwards 1993, 1998; Frankel and Romer 1999).

In the national income account, aggregate output can be decomposed into three components of consumption, investment and net exports. Change in any part can give rise to change in aggregate output and has an impact on economic growth. Because aggregate output is a function of labour input, change in any part of aggregate output will affect demand for labour, and then impact on employment.

Net exports equal export value minus import value. Using the annual change of net exports, we can calculate the contribution of trade to economic growth. Linking economic growth with employment growth, we can observe the impact of trade on employment. Table 9.6 shows that the share of net exports in GDP accounted for less than 5 per cent in absolute value, and its contribution to GDP growth fluctuated sharply from -34.6 per cent to 103.1 per cent.

This macroeconomic approach underestimates the contribution of trade to output and employment growth. There are also important effects in raising productivity through improved techniques, and more efficient allocation of resources across industries for a relatively labour-abundant economy like China at this stage of its development, it also increases the amount of employment expansion associated with a given amount of GDP growth. Some analysts suggest using trade growth or export growth to estimate the contribution of trade to economic growth. The crosscountry studies shows that 1 per cent of trade growth will lead to 0.2 per cent of GDP growth (Berloffa and Segnana 2004). Lin and Li (2002) found that 1 per cent of export growth led to 0.1 per cent of China's GDP growth.

The impact of trade on employment growth also depends on the elasticity of employment. Trade expansion in China comes mainly from the export and import of manufacturing goods, so it is reasonable to employ the elasticity of nonagricultural employment to calculate the aggregate impacts of trade on employment. Compared with the first half the 1990s, employment growth and employment elasticity in the second half of the decade were lower, but they rose in the first five years of the new century (Table 9.7).

Taking 0.1 per cent as the lower boundary and 0.2 per cent as the upper boundary of the contribution of trade growth to economic growth, Table 9.7 estimates the contribution of Chinese foreign trade to employment growth in different periods. As shown in the table, trade growth in the first half of the 1990s caused an annual 
Table 9.6 Macroeconomic contribution of net exports to economic growth, 1978-2004

\begin{tabular}{rrrrrrrr}
\hline $\begin{array}{c}\text { Net export } \\
\text { values } \\
\text { (100 million } \\
\text { yuan) }\end{array}$ & $\begin{array}{c}\text { Share in } \\
\text { GDP } \\
\text { (per cent) }\end{array}$ & $\begin{array}{c}\text { Contribution } \\
\text { to GDP } \\
\text { growth }\end{array}$ & & $\begin{array}{c}\text { Net export } \\
\text { values } \\
\text { (100 million } \\
\text { yuan) }\end{array}$ & $\begin{array}{c}\text { Share in } \\
\text { GDP } \\
\text { (per cent) }\end{array}$ & $\begin{array}{c}\text { Contribution } \\
\text { to GDP } \\
\text { growth }\end{array}$ \\
1979 & -19.6 & -0.5 & -2.7 & 1992 & 275.6 & 1.0 & -11.8 \\
1980 & -14.8 & -0.3 & 1.7 & 1993 & -679.4 & -2.0 & -24.2 \\
1981 & 11.3 & 0.2 & 10.9 & 1994 & 634.1 & 1.4 & 27.6 \\
1982 & 91.1 & 1.7 & 18.2 & 1995 & 998.5 & 1.7 & 5.1 \\
1983 & 50.8 & 0.8 & -7.1 & 1996 & $1,459.3$ & 2.1 & 6.8 \\
1984 & 1.3 & 0.0 & -5.5 & 1997 & $2,857.2$ & 3.8 & 22.9 \\
1985 & -366.9 & -4.2 & -34.6 & 1998 & $3,051.5$ & 3.9 & 4.6 \\
1986 & -255.2 & -2.5 & 15.5 & 1999 & $2,248.8$ & 2.7 & -13.4 \\
1987 & 11.5 & 0.1 & 22.5 & 2000 & $2,240.2$ & 2.5 & -0.5 \\
1988 & -151.1 & -1.0 & -10.8 & 2001 & $2,204.7$ & 2.3 & -0.9 \\
1989 & -185.5 & -1.1 & -3.2 & 2002 & $2,794.2$ & 2.7 & 7.4 \\
1990 & 510.3 & 2.8 & 103.1 & 2003 & $2,682.1$ & 2.3 & -1.6 \\
1991 & 617.5 & 2.9 & 4.0 & 2004 & $4,079.2$ & 3.0 & 10.3 \\
\hline
\end{tabular}

Note: The contribution of net exports to GDP growth is affected by GDP deflators.

Source: National Bureau of Statistics of China, 2005a. China Statistical Yearbook 2005, China Statistics Press, Beijing.

increment of employment of 2.5-5 million due to the large elasticity of employment. Because of the slowdown of trade growth and the decline of the elasticity of employment, the annual increment of employment dropped to 0.7-1.4 million in the second half of the 1990s. The acceleration of trade growth since 2001 has also produced a positive effect on employment growth, and promoted an annual increment of employment of 2.3-4.6 million in the first five years of this century.

Trade expansion has not only increased aggregate employment through economic growth, it sped up the adjustment of employment structure through a substitution effect. Trade liberalisation stimulates the development and export growth of domestic sectors that have a comparative advantage, and thus enlarges employment in those sectors, but it depresses the production of domestic sectors that have a comparative disadvantage.

The substitution of employment in comparative disadvantage sectors and the promotion of employment in comparative advantage sectors cause the reallocation of aggregate employment through the mechanism of employment creation and employment destruction. Meanwhile, changes in investment structure, especially the structure of foreign direct investment (FDI), also accelerate the pace of industrial 


\section{Table 9.7 Employment increments driven by trade growth, 1991-2005}

\begin{tabular}{lcccc}
\hline $\begin{array}{c}\text { Real growth of } \\
\text { trade (per cent) }\end{array}$ & $\begin{array}{c}\text { Employment } \\
\text { elasticity } \\
\text { (I) (million) }\end{array}$ & $\begin{array}{c}\text { Increments of } \\
\text { employment } \\
\text { (II) (million) }\end{array}$ & $\begin{array}{c}\text { Increments of } \\
\text { employment }\end{array}$ \\
1991-95 & 19.9 & 0.43 & 2.5 & 5.0 \\
$1996-2000$ & 10.8 & 0.19 & 0.7 & 1.4 \\
2001-05 & 22.5 & 0.26 & 2.3 & 4.6 \\
\hline
\end{tabular}

Note: 1) The growth of trade was deflated by using the GDP deflator; 2) increments of employment (I) was based on the calculation of 0.1 per cent contribution of trade to GDP growth; increments of employment (II) was based on the calculation of 0.2 per cent contribution of trade to GDP growth.

Source: Author's calculations.

restructuring and induce employment reallocation. With the decline or collapse of some industries, employees in those industries will be laid off and released for reallocation. In the meantime, the expansion or emergence of some industries will create new opportunities for employment.

Since Chinese foreign trade and FDI are concentrated mainly in coastal regions, fast trade growth here also affects spatial employment distribution. We can take the spatial distribution of manufacturing employment as an example. According to the geographic location and similarity in industrial structure, we divided the mainland into six regions (Table 9.8). Total manufacturing employment in the early 1990s had an upward trend, with an annual average growth of 2.6 per cent from 1990 to 1995 , but a decline afterwards, with an annual average growth of -3.9 per cent from 1995 to 2000. The number of manufacturing jobs in 2001 and 2002 increased, with an annual growth of 0.5 per cent and 2.8 per cent, respectively (Table 9.8).

Regional changes in employment, however, demonstrate a different picture. From 1993 to 2002, the numbers employed in manufacturing in the coastal region rose from 36.8 million to 39.7 million-an increase of 2.9 million; while manufacturing employment in the other five regions had a downward trend, with decreases of 2.1 million in the metropolis region, 4.7 million in the northeast region, 1.5 million in the central region, 1.4 in the southwest region and 1.3 million in the northwest region-a total reduction of 8 million.

Table 9.8 also shows that most manufacturing employment concentrates on the coastal and central regions, and their shares have kept an upward trend. From 1993 to 2002, the share of manufacturing employment in the coastal region rose 
Table 9.8 Distribution of manufacturing employment by region, 19932002

\begin{tabular}{|c|c|c|c|c|c|c|c|c|c|c|}
\hline & 1993 & 1994 & 1995 & 1996 & 1997 & 1998 & 1999 & 2000 & 2001 & 2002 \\
\hline \multicolumn{11}{|c|}{ Manufacturing employment (million) } \\
\hline Metropolis & 7.6 & 7.6 & 7.4 & 7.0 & 6.7 & 5.4 & 5.4 & 5.1 & 5.1 & 5.4 \\
\hline Northeast & 10.6 & 10.9 & 10.7 & 10.6 & 10.2 & 7.1 & 6.7 & 6.3 & 6.0 & 5.9 \\
\hline Coastal & 36.8 & 39.0 & 40.3 & 40.3 & 40.1 & 37.1 & 36.6 & 37.2 & 38.5 & 39.7 \\
\hline Central & 20.7 & 22.3 & 23.1 & 23.2 & 23.0 & 19.8 & 19.1 & 18.8 & 18.6 & 19.2 \\
\hline Southwest & 10.0 & 10.5 & 10.6 & 10.6 & 10.4 & 9.0 & 8.7 & 8.5 & 8.4 & 8.6 \\
\hline Northwest & 5.6 & 5.9 & 5.9 & 5.9 & 5.7 & 4.8 & 4.7 & 4.4 & 4.3 & 4.3 \\
\hline Total & 91.3 & 96.1 & 98.0 & 97.6 & 96.1 & 83.2 & 81.1 & 80.4 & 80.8 & 83.1 \\
\hline \multicolumn{11}{|c|}{ Distribution of manufacturing employment (per cent) } \\
\hline Metropolis & 8.3 & 7.9 & 7.5 & 7.2 & 6.9 & 6.5 & 6.6 & 6.4 & 6.3 & 6.5 \\
\hline Northeast & 11.6 & 11.3 & 10.9 & 10.8 & 10.6 & 8.5 & 8.3 & 7.8 & 7.5 & 7.0 \\
\hline Coastal & 40.4 & 40.6 & 41.1 & 41.3 & 41.8 & 44.6 & 45.1 & 46.3 & 47.6 & 47.8 \\
\hline Central & 22.6 & 23.2 & 23.6 & 23.8 & 24.0 & 23.8 & 23.6 & 23.4 & 23.0 & 23.1 \\
\hline Southwest & 11.0 & 10.9 & 10.8 & 10.8 & 10.8 & 10.8 & 10.7 & 10.6 & 10.3 & 10.3 \\
\hline Northwest & 6.2 & 6.1 & 6.1 & 6.1 & 5.9 & 5.8 & 5.7 & 5.5 & 5.3 & 5.2 \\
\hline Total & 100.0 & 100.0 & 100.0 & 100.0 & 100.0 & 100.0 & 100.0 & 100.0 & 100.0 & 100.0 \\
\hline
\end{tabular}

Note: Metropolis region includes Beijing, Shanghai, Tianjin; Northeast region includes Liaoning, Jilin, Heilongjiang; Coastal region includes Hebei, Jiangsu, Zhejiang, Shangdong, Gungdong, Hainan; Central region includes Shanxi, Anhui, Jiangxi, Henan, Hubei, Hunan; Southwest region includes Guangxi, Chongqing, Sichun, Tibet, Yunnan, Guizhou; Northwest region includes Inner Mongolia, Shaanxi, Gansu, Ningxia, Qinghai, Xinjiang.

Sources: National Bureau of Statistics of China, 1994-2005. China Statistical Yearbook, China Statistics Press, Beijing.

from 40.4 per cent to 47.8 per cent. The share of manufacturing employment in the central region rose from 22.6 per cent to 23.1 per cent, in the same period. Shares of manufacturing employment in the metropolis, northeast, southwest and northwest regions were all declining. Among them, the northeast region dropped from 11.6 per cent to 7 per cent in the same period, with the largest magnitude drop, of 4.6 percentage points.

Before 1998, the ratio of manufacturing goods imported and exported to Chinese manufacturing output was relatively low. The shocks of trade growth on the spatial distribution of manufacturing employment were therefore relatively small. At that time, the large decline in Chinese manufacturing employment was due mainly to industrial restructuring driven by changes in domestic demand. With the rapid growth of exports and imports of manufactured goods, however, trade played an increasingly important role in the spatial redistribution of manufacturing employment. 
Thanks to earlier opening-up and integration into the global economy, labourintensive manufacturing industries in the coastal region had a greater comparative advantage and their rapid growth promoted the growth of manufacturing employment in this region. In contrast, traditional manufacturing in the central and western regions was in capital-intensive heavy industries, and they had a comparative disadvantage under the shock of trade liberalisation; their shrinkage caused the decrease in manufacturing employment in those regions.

The coexistence of the above two factors led to rapid growth in the export of manufactured goods accompanied by a decline in manufacturing employment in the late 1990s. This situation has changed since China's accession into the WTO in 2001. The growth in exports of manufactured goods and the relative labour intensity of that production has promoted the growth of manufacturing employment.

Changes in the industrial distribution of FDI further stimulate the relocation of employment across sectors. Since China joined the WTO, FDI has concentrated increasingly in manufacturing sectors to take advantage of cheap labour. The manufacturing industry accounted for only 57.2 per cent of total Chinese FDI in 1998, but it leaped to 71 per cent in 2004. FDI moved increasingly in line with Chinese comparative advantage.

Because of the comparative disadvantage in agricultural and mining industries, their FDI shares are relatively low. Industries such as transportation, communication, storage and post, and so on, also have a low FDI share, because they are traditionally viewed as industries that have a natural monopoly, or are relevant to national security, so that institutional and policy obstacles to constrain FDI have remained in place. Although the government has encouraged foreign investment in infrastructure such as energy, transportation and ports, imperfect management systems have hindered the inflow of FDI to these industries.

Foreign-funded enterprises are mainly export-oriented, and account for more than half of Chinese exports. The expansion of foreign-funded enterprises has promoted employment growth in non state-owned enterprise sectors. Before 1978, China had no foreign investment. From 1979 to 1983 , the accumulated amount of FDI in China was only US\$1.8 billion. There was a large influx of FDI after 1985.

In 1985, the number of urban workers in FDI-funded sectors was 60,000, and the share of total urban workers was trivial. In 2004, however, the number of urban workers in FDI-funded sectors reached 10.3 million, and accounted for 3.9 per cent of total urban workers. In 1985, there were no FDI-funded enterprises in rural areas. In 2003, however, the number of rural workers in FDI-funded sectors was 7.3 million, and accounted for 5.4 per cent of total employment in township and village enterprises. 
Employment in urban and rural FDI-funded enterprises amounted to 15.9 million people in 2003, accounting for 4.1 per cent of non-agricultural employment.

\section{Changing patterns in labour supply and demand}

\section{Demographic predictions of labour supply and demand}

Population age structure changes over time in response to long-run economic and social forces. By collecting data from 129 countries, the LOWESS estimation method depicts a non-parametric relationship between per capita income and age structure (Figure 9.5). The graphs on the left and right describe, respectively, the relationships between per capita gross national income (GNI), adjusted by purchasing power parity, and the proportion of the working-age population (aged 15-64 years) in the total population and the proportion of elderly (65 years and older) in the total population.

In the early phase of development, as per capita income increases, the proportion of the working-age population and the old-age population increase in line with each other, as indicated by the positive slope of the fitted lines in the two graphs Figure 9.5). When per capita income reaches certain levels, the proportion of the working-age population begins to increase more slowly, whereas the proportion of the old-age population increases more quickly. The slopes of the fitted lines, after the turning points are reached, become flatter in the former case (on the left) and steeper in the latter case (on the right).

In both graphs, China stands above the fitted lines, indicating that compared with countries with similar levels of per capita income, China has a larger proportion of working-age and old-age populations. That is, China is not only in its golden population structure, it has been confronted sooner than other countries with an ageing population, as its family planning policies have caused a significant drop in fertility, resulting in a rapid decline in the proportion of youth and a quick increase in the proportion of the elderly.

When the pace of the decline in the proportion of youth exceeded that of the increase in the proportion of the elderly, China began to enjoy a sufficient labour supply, a result of productive population structure. As the demographic transition process moves forward, the growth of the working-age population will slow, while population ageing speeds up. China is now at the turning points from which the fitted line for the proportion of the working-age population becomes flatter and the fitted line of the proportion of the old-age population becomes steeper (Figure 9.5).

The United Nations predicts that the ratio of the working-age population to the total population will continue to increase until 2010 , and the absolute number of 
Figure 9.5 Per capita income versus population age structure
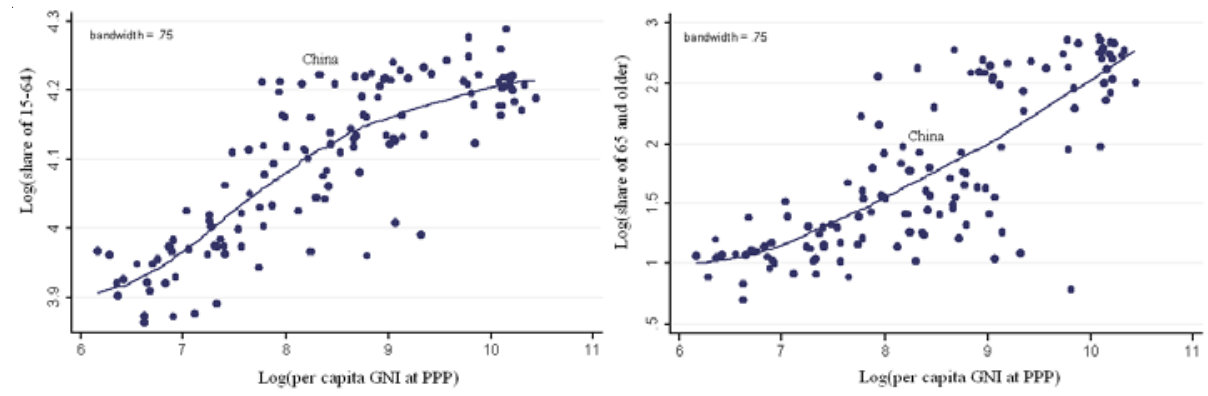

Notes: Purchasing power parity (PPP) adjusted per capita gross national income (GNI) is for 2001; the proportion of population age is for 2000.

Sources: World Bank, 2003. World Development Indicators, World Bank, Washington. United Nations, 2003. World Population Prospects: the 2002 revision, United Nations Population Division, Department of Economic and Social Affairs, Washington. Available from www.un.org/ esa/population/publications/wpp2002

the working population will reach its peak of approximately one billion people in 2015, before beginning to shrink (United Nations 2003). The China Center for Population and Development predicts a similar pattern of population structure changes: the proportion of the working population will reach its peak of 72.1 per cent in 2013 and the total working-age population will reach its highest number, 997 million, in 2016 (Wang 2006). The entire process characterises China as becoming an ageing but not an affluent society.

Examining the working-age population by dividing it into four groups-15-24, 25-39, 40-54 and 55-64 years-we find that between 2000 and 2030, the proportions of the 15-24 and the 25-39 year-old groups in the total population will decline steadily, whereas the proportion of the 55-64 year-old group will increase and the proportion of the 40-54 year-old group will increase first and then decline after a certain point (United Nations 2003). This trend indicates that not only will the Chinese population age over time, the working-age population itself will tend to age 25 years from now. Furthermore, if a larger part of the 15-24 year-old group continues its schooling as higher education expands and a larger part of the 5564 year-old group quits the labour market as a result of the discouraged-worker 
effect or the income effect (both tend to reduce labour-force participation), the labour supply will fall off further.

Observing the already diminishing net growth of the working-age population and the constantly increasing demand for workers in non-agricultural sectors during the eleventh Five-Year Plan (2006-10), we can expect a possible gap between supply and demand for labour in the near future (Figure 9.3). We assume that agriculture will have no further demand for workers; therefore, the incremental amount of the working-age population is a reasonable labour supply base for nonagricultural sectors.

Providing three scenarios for a non-agricultural growth rate (high growth of 10 per cent, medium growth of 9 per cent and low growth of 8 per cent) and two employment elasticities for non-agricultural growth (1 percentage point in growth creates a 0.297 percentage rise in employment — the average level from 1991 to 2003), as high elasticity and a 1 percentage point in growth create a 0.230 percentage point rise in employment (a half-standard deviation lower than the former) as low elasticity, we plot the six combinations of predicted labour demand of non-agricultural growth against the labour supply (incremental working-age population).

From 2004 on, the net increase of new entrants to the labour market tends to lag behind the various scenarios of an increase in labour demand and the gap widens over time (Figure 9.6). Although agriculture will continue to release its surplus labour as a result of enhanced labour productivity in the sector, structural labour shortages in terms of region, sector and specific skills are likely to occur from time to time.

Demographic transition provided an opportunity for China to take advantage of its demographic dividend in the mid $1960 \mathrm{~s},{ }^{2}$ but only after the initiation of reform could the opportunity have been used to promote economic growth. During the reform period, the potential demographic dividend was capitalised through trade liberalisation, development of factor markets and fast economic growth. Taking the total-dependence ratio as a proxy of the advantageous population structure (Figure 9.7) between 1982 and 2000, each 1 per cent decrease in the dependence ratio led to a 0.115 per cent growth in per capita GDP; that is, the decline in the total-dependence rate contributed to one-quarter of the per capita GDP growth in the reform period (Cai and Wang 2005).

The demographic dividend is performing a typical pattern of 'easy come, easy go'. That is, as a consequence of fast demographic transition, the earlier the high proportion of working-age population comes, the sooner it is gone. The fact, on the one hand, that demographic transition in China happened in a short time and 
Figure 9.6 Predictions for labour supply and demand in non-agricultural sectors, 2004-10

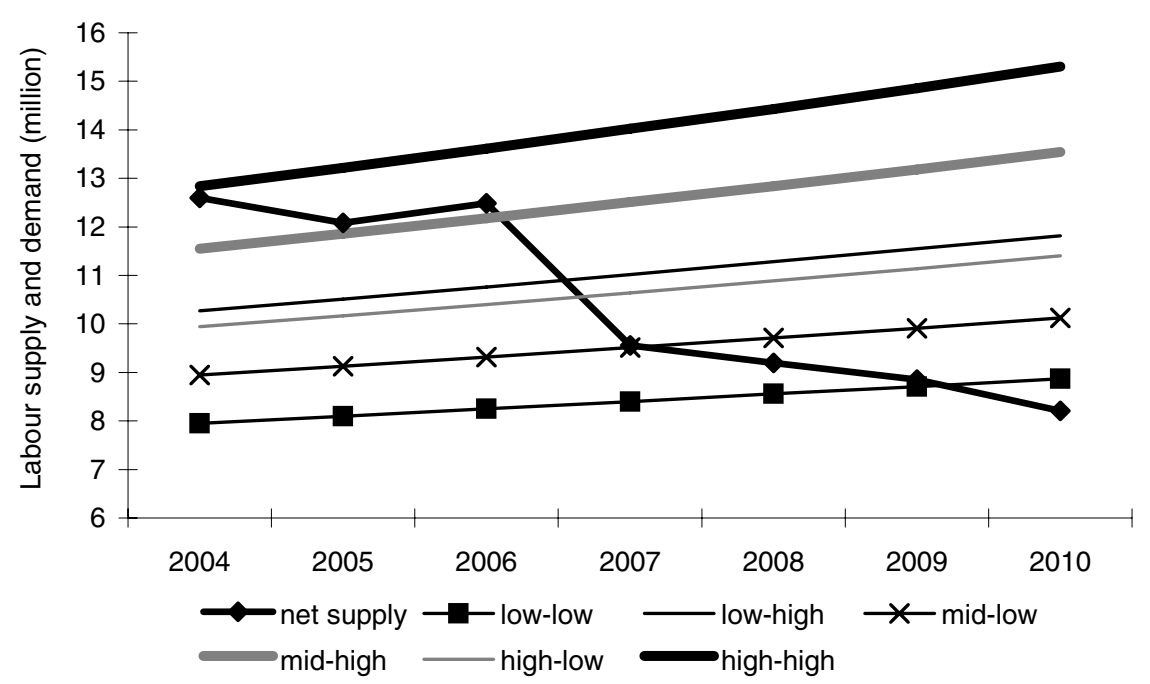

Source: Fang, C., Yang, D. and Meiyan, W. (eds), forthcoming. An Overview on China's Labour Market, in National Development and Restructuring Commission.

in a fast manner has no doubt provided China with an extra source of economic growth. On the other hand, it leaves a very short period for the Chinese economy to enjoy low population dependence. Population dependence will stay at a low level only for a short time in the second decade of this century and will increase rapidly afterwards (Figure 9.7). The lowest point of population dependence will be reached in 2013, when the ratio of the dependent population to the working-age population will be 38.8 per cent. After that, the population-dependence ratio will increase, mainly as a result of the increase in elderly dependence.

Population ageing is followed by a reduction in labour supply everywhere at any time in history. The impact of ageing on the sustainability of economic growth differs across stages of socioeconomic development. In most industrial countries that have already finished their demographic transition, population ageing is accompanied by high per capita income. The relative abundance of physical and human capital enables these countries to accomplish a necessary upgrading of industrial structure by substituting capital for labour, and generally leads to a 


\section{Figure 9.7 Changes in population dependence, 1949-2048}

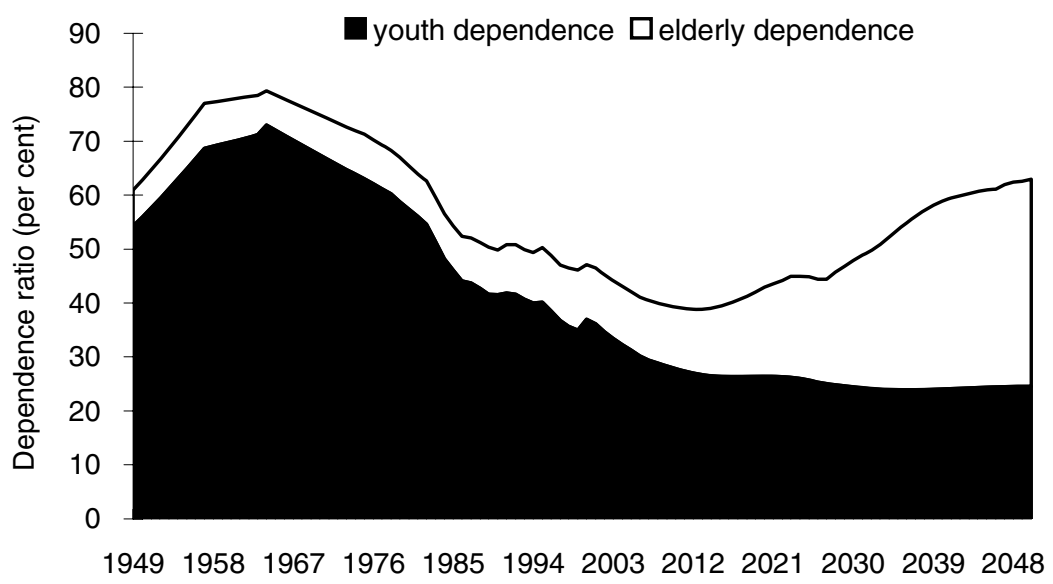

Sources: Figures on dependence are from National Bureau of Statistics of China, various years. China Statistical Yearbook 2005, China Statistics Press, Beijing, with estimations to fill in the years without data. Figures on savings rates are from ibid. and Wang, G., 2006, 'Population projection and analysis', in Cai Fang (ed.), Green Book of Population and Labour Demographic Transition and Its Social and Economic Consequences, Social Sciences Academic Press, Beijing.

transformation from an economy dominated by labour-intensive industries to an economy dominated by capital-intensive industries.

A shortage of skilled workers in China would result in an increase in skilled workers' wages, and would hamper China's comparative advantage in labourintensive industries without providing a gain in new comparative advantage in capital-intensive industries, because China's per capita income level is still low in terms of international ranking.

As early as 2003, a shortage of migrant workers occurred in the Pearl River Delta region. At that time, most observers considered the labour shortage to be a cyclical phenomenon caused by the upsurge of the regional export-driven economy under the circumstances of underpayment, abuse and a lack of security for migrant workers. Since then, the phenomenon of labour shortages has spread to the Yangtze River Delta region, and even to some central provinces, such as Jiangxi, Anhui and Henan, from which migrant labourers are generally sent. 
The analysis of population age structure addressed in this chapter suggests that the causes of labour shortages have a demographic root and, therefore, tend to intensify over time. Since the 1990s, wage rates in China's manufacturing sector have increased rapidly in comparison with most parts of the world, which will soon put a a dent in international competitiveness in manufacturing (Banister 2005; Cai 2005).

\section{Impact on Chinese manufacturing competitiveness}

China's trade expansion benefits largely from its huge advantage of cheap labour. Given the production technology, there is a negative relationship between labour costs and corporate profit (capital returns). International commodity markets are generally perfectly competitive, and manufacturers are passive takers of market prices, therefore, labour costs have an important impact on returns to investment. Low labour costs will increase returns to investment, while high labour costs will decrease returns, so labour costs are important determinants of competitiveness.

Compared with industrial economies, China has an absolute advantage in labour costs in the manufacturing industry, but the gap has been narrowed dramatically. In 1995, China's annual average manufacturing wage was equivalent to 1/57-1/24 that of industrial economies, but increased to $1 / 26-1 / 13$ that of industrial economies in 2002 (Table 9.9). The decline of China's absolute advantage in labour costs can be attributed to the rapid growth in wage rates. From 1995 to 2002, the annual growth rates of manufacturing wages were 11.6 per cent in China, -2.8 per cent in Japan, 3.1 per cent in the United States, 4.3 per cent in the United Kingdom, 2.5 per cent in South Korea, 2.2 per cent in Singapore and 3.3 per cent in Hong Kong. Even if the increasing speed is considered, China will maintain an advantage in manufacturing labour costs in the longer term owing to its significant absolute advantage over the industrial economies. This advantage will, however, face challenges from China's neighbouring countries, which have experienced fast economic growth, such as Malaysia, India, Thailand and Vietnam.

India's labour costs in the manufacturing industry in 1995 were about 70 per cent those of China, and this gap has been widening (Table 9.9). With increasing exports of manufacturing products from neighbouring countries, China's manufacturing exports will face a more competitive environment. If the labour costs of China's manufacturing products continue to increase, the competitive advantage of manufacturing product exports will be weakened.

Manufacturing wages can reflect one side of the international competitiveness of the manufacturing industry, but the productivity of the manufacturing industry represents another side of international competitiveness. The former measures labour input, while the latter measures labour output. Combining those two figures, 
we can compare the international competitiveness of the manufacturing industry with countries without adjusting exchange rates. If we define the competitiveadvantage index as labour productivity divided by wage costs, this indicator reflects, to a certain extent, returns to investment and profitability.

In Table 9.9, the values of competitive-advantage indices for China's manufacturing industry were about 4-4.5, greater than all other countries in the table, and 1.5-3 times that in industrial countries. These figures show that China's manufacturing industry has a strong competitive advantage. The same trend of labour cost growth and productivity growth keep the competitive-advantage index almost unchanged. It has, however, had a slight decline since 1998 because labour cost growth is a little higher than productivity growth.

Table 9.9 International comparison of manufacturing wage costs, 19952002

\begin{tabular}{|c|c|c|c|c|c|c|c|c|c|}
\hline \multicolumn{3}{|c|}{1995} & 1996 & 1997 & 1998 & 1999 & 2000 & 2001 & 2002 \\
\hline \multicolumn{10}{|c|}{ Annual average manufacturing wage (US\$) } \\
\hline China & \multicolumn{2}{|c|}{619} & 679 & 716 & 853 & 941 & 1,057 & 1,181 & 1,329 \\
\hline $\begin{array}{l}\text { Japan } \\
\text { United }\end{array}$ & \multicolumn{2}{|c|}{35,569} & 31,296 & 28,485 & 26,547 & 30,667 & 32,638 & 29,376 & 28,366 \\
\hline $\begin{array}{l}\text { States } \\
\text { United }\end{array}$ & \multicolumn{2}{|c|}{25,667} & 26,520 & 27,331 & 27,976 & 28,808 & 29,786 & 30,701 & 31,803 \\
\hline \multicolumn{7}{|l|}{ South } & & & 34,412 \\
\hline Korea & \multicolumn{2}{|c|}{17,486} & 18,813 & 16,729 & 10,999 & 14,894 & 16,993 & 15,824 & 17,812 \\
\hline Singapore & \multicolumn{2}{|c|}{18,264} & 19,740 & 20,097 & 19,474 & 19,844 & 21,132 & 20,876 & 21,137 \\
\hline Malaysia & \multicolumn{2}{|c|}{4,801} & 5,318 & 5,161 & .. & .. & 4,383 & 4,835 & .. \\
\hline India & \multicolumn{2}{|c|}{434} & 402 & 367 & 345 & 429 & 336 & .. & .. \\
\hline \multicolumn{10}{|c|}{ Competitive index } \\
\hline China & & 4.0 & 4.3 & 4.5 & 4.5 & 4.4 & 4.4 & 4.3 & 4.1 \\
\hline Japan & & 2.4 & 2.4 & 2.4 & 2.4 & 2.4 & 2.4 & 2.3 & .. \\
\hline United Sta & ates & 2.5 & 2.4 & 2.4 & 2.5 & 2.6 & 2.6 & 2.4 & .. \\
\hline United King & gdom & 1.7 & 1.7 & 1.7 & 1.6 & 1.6 & 1.6 & 1.5 & .. \\
\hline Korea & & 1.7 & 1.7 & 1.8 & 2.3 & 2.1 & 2.0 &.. & .. \\
\hline Singapore & & 2.6 & 2.6 & 2.6 & 2.4 & 2.4 & 2.7 & 2.5 & 3.0 \\
\hline Hong Kong & & 1.4 & 1.4 & 1.4 & 1.4 & 1.3 & 1.5 & 1.3 & 1.4 \\
\hline Malaysia & & 2.7 & 2.8 & 2.8 &.. &.. & 3.2 & .. & .. \\
\hline
\end{tabular}

Note: 1) Figures in this table have been changed into US dollars according to the currency exchange rate of individual countries; 2) because of differences in wage statistics, hourly wages in the US and UK are multiplied by 40 hours a week and 52 weeks a year to get the annual wages; monthly wages in other countries are multiplied by 12 months to get the annual wages; 3 ) the competitive advantage index equals labour productivity divided by labour cost. Source: International Labour Organisation, http://laboursta.ilo.org/. 
The Turning Point in China's Economic Development

\section{Conclusion}

GDP growth must be maintained at a high rate if China is to accomplish its goal of building a well-off society, with total GDP four times that of 2000 by 2020 . The demand for labour, especially in the manufacturing and service sectors, will be strong in the coming decades of continued economic growth. The ageing population, however, is reducing the increase in the working-age population and, before an absolute labour shortage occurs, structural shortages will occur frequently. Furthermore, not only might the high savings rate in China drop because of its ageing population, international capital flows might become uncertain because of global ageing (Jackson 2005).

In order to sustain economic growth, a fundamental transformation of the growth pattern should be taken in China. In the economic development process of industrialised economies, the limitations of population growth and, therefore, labour scarcity have generated diminishing returns to capital, leading to a transformation of economic growth patterns from input-driven to productivity increase-driven growth.

The more rapidly completed demographic transition in East Asian economies, including in China, has offered them a demographic dividend (Bloom et al. 2002; Cai and Wang 2005), so as to defer the phenomenon of diminishing returns to capital. As the demographic transition continues, the characteristic of an unlimited labour supply will disappear and an era of labour shortages arrive, which requires an urgent transformation of growth patterns. The Chinese economy is now facing the transformation from input-driven to productivity-driven economic growth.

International experiences suggest that once labour shortages emerge, a host of institutional arrangements change accordingly. For example, state policies become more balanced in the provision of public services between rural and urban areas, government regulations tend to abolish institutional barriers deterring labour mobility and protection of labour rights, industrial relations shift from favouring employers to favouring employees, and trade unions play a greater role in coordinating interests between employers and employees.

The unique household registration (hukou) system established in the beginning of the planning system in the late 1950s still serves as an institutional obstacle preventing the rural labour force from permanently migrating to and working in cities. This is the best time for China to readjust institutional arrangements to acclimatise itself to a new era of labour market structure.

Studies show that the improvement of resource reallocation efficiency will not only be one source of China's sustained economic growth, it can help to maintain 
China's manufacturing competitiveness through the development of a labour market system. A World Bank simulation suggests that moving 1, 5 and 10 per cent of the labour force out of agriculture and distributing them into other sectors will, respectively, add 0.7, 3.3 and 6.4 per cent to China's total GDP (World Bank 2005).

In their model, Whalley and Shuming (2004) testify that in removing migration restrictions, wage and income inequality disappears. Abolition of the various institutional obstacles that hinder the development of labour markets can build a solid bridge of labour transfer between sending and receiving areas, and enhances migration mobility between rural and urban areas and across regions to mitigate the pressure of wage rises and regional imbalance, so as to maintain Chinese manufacturing competitiveness.

In the long term, wage rises are an unavoidable trend with changes in labour supply and demand. In this situation, it is necessary for China to increase human capital investment in education, training, health and medical care to improve labour skills and to offset the negative effects of wage rises through the improvement of productivity.

\section{Notes}

1 In 2003, the Ministry of Labor and Social Security broadened the range of ages for registering unemployment to 16-60 for males and 16-55 for females.

2 As a result of demographic transition, population age structure can be more productive in a certain period than in other periods, and, therefore, it adds an extra source of economic growth. This source of growth caused by population structure is recognised as demographic dividend (Bloom et al. 2002). 